\title{
PEMANFAATAN SISTEM PELAYANAN PUBLIK DALAM MENINGKATKAN KUALITAS HUBUNGAN MASYARAKAT DI KEMENTERIAN AGAMA KABUPATEN TUBAN
}

\author{
Silvia Diah Rahmawati, Vira Sholikah, Muhammad Nuril Huda \\ UIN Sunan Ampel, Surabaya - Indonesia | silviadiahr@gmail.com
}

\begin{abstract}
Abstrak: Artikel ini bertujuan agar mengetahui tingkat pemanfaatan pogram pelayanan publik, hal ini digunakan untuk meningkatan suatu kaulitas hubungan masyarakat dengan kementrian agama kabupaten Tuban.jurnal ini menggunakan metode penelitian kualitatif dengan pendekatan deskriptif. Karena di ketahui bahwa dewasa ini pelayann publik masih banyak yang blum berjalan dengan sebagaimana mestinya. Masih banyak Lembaga-lembaga publik yang belum melakukan pelayanan dengan maksimal masih banyak pelayanna-pelaynan yang kurang salah satu masalahnya ada di pelayana publik, entah itu pelayanan Kesehatan, pelayanan administratif dan lainnya. Pelayanan publik merupakan tujuan dari penyedaiaan barang dan jasa. Penyediaan barang dan jasa yang telah dilakukan untuk mencapai tujuan dan misi negara. Tujuan misi negara biasanya diatur dalam konstitusi atau peraturan perundangan lainnya. Contohnya pelayanan untuk memenuhi kebutuhan di Pendma. Adapun pelayanan publik adalah sebagai pemberian layanan (melayani) keperluan orang atau masyarakat yang memiliki kepentingan pada organisasi itu sesuai dengan aturan pokok dan tata cara yang telah ditetapkan.Dengan adanya jurnal ini diharapkan pelayanan Kantor Agama di Kabupaten Tuban, dapat meningkat dan berjalan sebagaimana mestinya.
\end{abstract}

Keywords: Sistem Pelayanan Publik, Hubungan Masyarakat

\section{Pemdahuluan}

Saat ini Pelayanan Publik di Indonesia belum berjalan dengan maksimal atau dapat dikatakan belum cukup memenuhi kebutuhan dasar dalam rangka menyediakan layanan public. Contohnya seperti hal nya dalam sector pelayanan kesehatan, pelayanan 
administrative, pelayanan pendidikan, pelayanan peradilan, pelayanan keamanan jasa, pelayanan barang dan pelayanan kemasyarakatan dll. Dalam menyediakan pelayanan public pemerintah harus bertanggung jawab dan memberikan pelayanan yang terbaik bagi masyarakat demi peningkatan pelayanan publik.

Pengertian Pelayanan Publik, Menurut Batinggi menyatakan bahwa Pelayanan Publik adalah perbuatan atau kegiatan yang dilakukan oleh pemerintah untuk mengurus hal-hal yang diperlukan masyarakat atau khalayak umum. Dengan itu, setiap warga waijb menerima pelayanan public yang terbaik yang diberikan oleh Pemerintah.1 Sedangkan Menurut Ratminto Pelayanan Publik adalah segala bentuk jasa pelayanan, baik dalam bentuk barang maupun jasa publik yang pada prinsipnya menjadi tanggung jawab dan dilaksanakan oleh Instansi Pemerintah di pusat, di daerah, dan di lingkungan Badan Usaha Milik Negara atau Badan Usaha Milih Daerah, dalam rangka pelaksanaan ketentuan peraturan perundang-undangan. 2

Pengertian menurut A.S. Moenir menyatakan bahwa Pelayanan Umum adalah suatu usaha yang dilakukan kelompok atau seseorang atau birokrasi untuk memberikan bantuan kepada masyarakat dalam rangka mencapai suatu tujuan tertentu. 3

Dari berbagai pendapat para ahli pengertian Pelayanan Publik diatas dapat disimpulkan bahwa, Pelayanan Publik adalah sebagai pemberian layanan atau melayani keperluan orang atau masyarakat dan/atau organisasi lain yang mempunyai kepentingan pada organisasi itu, sesuai dengan aturan pokok dan tata cara yang ditentukan dan ditujukan untuk memberikan kepuasan kepada penerima pelayanan.

${ }^{1}$ Dr. Kridawati Sadhana, M.S, “Etika Birokrasi dalam Pelayanan Publik”, (Malang: CV. Citrab Malang, 2010) 131.

2 Ratminto dan Atik Septi Winarsih, "Manajemen Pelayanan: Pengembangan Modal Konseptual, Penerapan Culture Charter dan Standar Pelayanan Minimal" (Yogyakarta: Pustaka Pelajar, 2016), 1.

${ }^{3}$ Moenir, "Manajemen Pelayanan Umum", (Jakarta: PT Bumi Aksara, 1995), 7. 
Berbicara masalah pelayanan publik di sector pendidikan. Banyak permasalahan yang dapat di ketahui contohnya seperti sarana pendidikan, pelaku pendidikan mulai dari pengajar hingga siswa yang diajar.

Pelayanan publik merupakan tujuan dari penyedaiaan barang dan jasa. Penyediaan barang dan jasa yang telah dilakukan untuk mencapai tujuan dan misi negara. Tujuan misi negara biasanya diatur dalam konstitusi atau peraturan perundangan lainnya. Contohnya pelayanan untuk memenuhi kebutuhan di Pendma. Adapun pelayanan publik adalah sebagai pemberian layanan (melayani) keperluan orang atau masyarakat yang memiliki kepentingan pada organisasi itu sesuai dengan aturan pokok dan tata cara yang telah ditetapkan.

Pelayanan publik dalam pendidikan merupakan salah satu kebutuhan yang paling mendasar bagi setiap manusia pendidikan akan membentuk karakter. Hampir tidak ada upaya pendidikan yang dapat mengabaikan peranan biaya, sehingga dikatakan bahwa tanpa biaya proses pendidikan disekolah tidak akan berjalan. Biaya dalam pengertian ini memiliki cakupan yang luas, yakni semua jenis pengeluaran yang berkenaan dengan penyelenggaraan pendidikan, baik dalam bentuk uang maupun barang. Dalam pengertian ini misalnya, iuran siswa adalah jelas merupakan biaya, tetapi sarana fisik, buku sekolah, dan guru.4

Tujuan pelayanan publik adalah memuaskan masyarakat, untuk mencapai kepuasan itu dituntut kualitas pelayanan publik yang professional.5 Lahirnya Undang-undang pelayanan publik, yaitu UU No. 25 Tahun 2009 dimaksudkan untuk memberikan kepastian hukum dalam hubungan antara masyarakat dan penyelenggara

\footnotetext{
${ }^{4}$ Satriadi, Tubel Agusven, Surya Kusumah, "Kualitas Pelayanan Publik Sektor Pendidikan

(Studi Pelayanan Program Dana Bos Tingkat Sma Pada Dinas Pendidikan Kota Tanjungpinang)", jurnal manajemen dan bisnis tanjung pinang, Vol.02 No.01 2018, 30-31.

5 Robi Cahyadi Kurniawan, "Inovasi Kualitas Pelayanan Publik Pemerintahan Daerah", Fiat Justisia Journal of Law, Vol.10 No.03 juliseptember 2016,573.
} 
dalam pelayanan publik, yaitu: 1) Terwujudnya batasan hubungan yang jelas, tentang hak, tanggung jawab, kewajiban dan kewenangan seluruh pihak yang terkait dengan penyelenggaraan pelayanan publik; 2) Terwujudnya sistem penyelenggaraan pelayanan publik yang layak sesuai dengan azas-azas umum pemerintahan dan koorporasi yang baik; 3) Terpenuhinya penyelenggaran pelayanan publik sesuai dengan peraturan perundang-udangan; dan 4) Terwujudnya perlindungan dan kepastian hukum bagi masyarakat dalam penyelenggaraan pelayanan publik. 6

Tujuan pelayanan Publik adalah memberikan pelayanan yang dapat memenuhi dan memuaskan pelanggan atau masyarakat serta memberikan fokus pelayanan kepada pelanggan. Pelayanan prima dalam sektor publik didasarkan pada aksioma bahwa "pelayanan adalah pemberdayaan". Pelayanan pada sektor bisnis berorientasi profit, sedangkan pelayanan prima pada sektor publik bertujuan memenuhi kebutuhan masyarakat secara sangat baik atau terbaik.

Perbaikan pelayanan sektor publik merupakan kebutuhan yang mendesak sebagai kunci keberhasilan reformasi administrasi negara. Pelayanan publik bertujuan : a) Untuk memberikan pelayanan yang bermutu tinggi kepada pelanggan/pengguna produk, b) Untuk menimbulkan keputusan dari pihak pelanggan agar segera membeli barang/jasa yang ditawarkan pada saat itu juga, c) Untuk menumbuhkan kepercayaan pelanggan terhadap barang/jasa yang ditawarkan, d) Untuk menghindari terjadinya tuntutan-tuntutan yang tidak perlu dikemudian hari terhadap produsen, e) Untuk menciptakan kepercayaan dan kepuasan kepada pelanggan, f) Untuk menjaga agar pelanggan merasa diperhatikan segala kebutuhannya. g) Untuk mempertahankan pelanggan/pengguna produk.

Manfaat pelayanan publik adalah sebagai acuan pengembangan penyusunan standar pelayanan, Meningkatkan pengetahuan dasar tentang sistem penyelenggaraan pemerintahan negara bidang tugas,

${ }^{6}$ Rahmawati, " Administrasi dan Pelayanan Publik Ditinjau Dari Kemaslahatan Umat", jurnal pilar Vol.02 No.02 juli-desember 2014, 199200. 
budaya organisasinya dalam melaksanakan tugas dan perannya sebagai pelayanan masyarakat, Meningkatkan pengetahuan, keahlian, keterampilan, dan sikap untuk dapat melaksanakan tugas jabatan secara profesional dengan dilandasi kepribadian dan etika PNS sesuai dengan kebutuhan instansi.7

Manajemen Hubungan Masyarakat merupakan manajemen yang mengatur antara lembaga kepada masyarakat. Manajemen humas mempunyai peran penting dalam meningkatkan kualitas layanan, karena bagaimanapun suatu lembaga tidak berkembang dengan baik apabila tidak ada hubungan baik kepada lembaga lain atau masyarakat. 8

Hubungan Masyarakat salah satu fungsi manajemen yang diadakan untuk menilai dan menyimpulkan sikap-sikap public, menyesuaikan prosedur instansi atau Lembaga untuk mendapatkan kedekatan kepada masyarakat.9

Frank Jefkins menerangkan bahwa humas yaitu suatu kegiatan komunikasi yang terencana, baik dalam lembaga maupun luar lembaga.10 Sedangkan Sondang P. Siagan humas adalah semua kegiatan yang dijalankan suatu lembaga bersama pihak-pihak lain dalam rangka menjalin dan mempertahankan hubungan baik.11

Oemi Abdurrahmad M.A menyatakan hubungan masyarakat adalah menjalin hubungan baik antara pelanggan atau kollega pada

\footnotetext{
${ }^{7}$ Jimmy Arief Saud Parsaoran, ”Dasar - Dasar Pelayanan Publik Dalam Rangka Memenuhi Pelayanan Prima Di Sektor Pemerintahan",2017, http://bkpsdmd.babelprov.go.id/content/dasar-\%E2\%80\%93-dasarpelayanan-publik-dalam-rangka-memenuhi-pelayanan-prima-di-sektorpemerintahan, diakses tanggal 21 oktober 2020

${ }^{8}$ Elfidawati, "Manajemen Humas Dalam Meningkatkan Mutu Madrasah Studi Kasus di Madrasah Ibtidaiyah Terpadu (MIT) AS-SALAM AMBON", al- iltizam, Vol.1 No.1 , Juni 2016, 34. https://core.ac.uk/download/pdf/229359603.pdf, diakses pada tanggal 14 Oktober 2020, 14.00

${ }^{9}$ Tatang M. Amirin, "Manajemen Pendidikan", (Yogyakarta: UNY Pres, 2011), 93

${ }^{10}$ Frank Jekins, "Public Realiton, Penerjemah Haris Munandar", (Jakarta: Erlangga, 1992), 92

${ }^{11}$ Sondang P. Siagian, "Filsafat Administrasi", (Jakarta: Gunung Agung, 1982), 96.
} 
suatu lembaga bertujuan memberikan pengertian, menanamkan motivasi, dan partisipasi.

Maka dari penjelasan diatas maka dapat disimpulkan bahwa humas adalah salah satu kegiatan manajemen lembaga atau instansi formal maupun nonformal yang bertujuan untuk menjalin dan mempertahankan hubungan, biasanya humas sendiri sebagai alat bantu untuk menyampaikan pesan.

Edwar L. Bernays menerangkan bahwa humas memiliki fungsi, adalah: (a) Membujuk masyarakat untuk mengubah sikap dan tindakannya. (b) mengusahakan untuk mengintegritaskan sikap dan tindakan lembaga dengan PTK, maupun PTK dengan walisiswa. (c) menjalin hubungan masyarakat yang baik.12

Fungsi dari Humas di lembaga sekolah sesuai dengan UndangUndang Republik Indonesia Nomor 20 Tahun 2003 bahwa "Sistem Pendidikan Nasional harus menjamin pemerataan kesempatan pendidikan, peningkatan mutu serta relevansi dan efisiensi manajemen pendidikan untuk menghadapi tantangan sesuai dengan tuntutan perubahan kehidupan lokal, nasional dan global sehingga perlu dilakukan pembaharuan pendidikan secara terencana, terarah dan berkesinambungan"13

Menurut Cultip, Center dan Broom peran humas berarti sebagai manajemen yang membangun, mempertahankan dan meningkatkan hubungan baik dan harmonis antara lembaga satu dengan yang lain, humas sendiri memegang penting dalam lembaga karena gagal atau suksesnya sebuah lembaga juga bergantung pada bagian humas.14

Kementerian Agama Republik Indonesia (Kemenag RI) adalah kementerian dalam pemerintah Indonesia yang membidangi urusan agama. Kantor Kementerian Agama dibagi menjadi tiga wilayah yakni kantor pusat, kantor wilayah, dan kantor kabupaten. Kementerian Agama Kabupaten Tuban merupakan salah satu

\footnotetext{
${ }^{12}$ Onong Uchjana Effendy, "Hubungan Masyarakat", (Bandung: Remaja Rosdakarya, 2006), 23.

${ }_{13}^{13}$ Undang-Undang Republik Indonesia Nomor 20 Tahun 2003.

14 Cultip, Center \& Broom, "Effective Public Releation(Edisi kesembilan)", (Jakarta: Kencana, 2006), 6.
} 
kantor kementerian tingkat kabupaten. Prospek kerja di kantor Kemenag Tuban terbagi menjadi enam bidang, diantaranya yaitu bidang Bimbingan Masyarakat Islam (BIMAS ISLAM), bidang Penyelenggaraan Haji dan Umrah, bidang Pendidikan Madrasah (PENDMA), bidang Pendidikan Diniyah dan Pondok Pesantren (PD Pontren), bidang Pendidikan Agama Islam (PAIS), dan bidang Penyelenggaraan Zakat dan Wakaf.

Bidang Pendidikan Madrasah (PENDMA) merupakan salah satu bidang yang ada di Kementerian Agama Kabupaten Tuban merupakan salah satu bidang yang melayani segala urusan yang berkaitan dengan Lembaga Pendidikan Islam yang meliputi RA/MI/MTS/MA.

Dengan menggunakan System pelayanan public di bidang pendma maka dapat meningkatkan kualitas layanan. Apabila pelayanan yang dirasakan sesuai denga apa yang diharapkan maka bisa dikatakan memuaskan. berdasarkan ada adanya latar bekang diatas maka fokus penelitian ini adalah Pelayanan Publik di Bidang Pendidikan Madrasah (Pendma) Di Kementrian Agama Kabupaten Tuban.

\section{Metodologi}

Penelitian ini menggunakan penelitian kualitatif. Lokasi penelitian dilakukan di Kementrian Agama Kabupaten Tuban, Seksi Pendidikan Madrasah. metode pengumpulan data menggunakan, wawancara, observasi dan studi literasi. subjek dalam penelitian ini meliputi: Bapak Hadi Sarjono selaku Plt. Pendidikan Madrasah dan Bapak Khoirul Fata Selaku Pengelola Pendidikan.

Penelitian menggunakan metode deskriptif yang mana metode ini lebih tepat digunakan oleh peneliti karena data yang diteliti berupa kalimat tertulis ataupun lisan, bukan menggunakan hitungan atau angka. Sehingga peneliti ini diharapkan dapat mendeskripsikan dan menjelaskan secara mendalam mengenai Pemanfaatan Sistem Pelayanan Publik Dalam Meningkatkan Kualitas Hubungan Masyarakat di Kementerian Agama Kabupaten Tuban. 


\section{Hasil dan Pembahasan}

Pelayanan publik adalah Serangkaian kegiatan dalam rangka pemenuhan kebutuhan pelayanan sesuai dengan peraturan perundang-undangan bagi setiap warga negara dan penduduk atas barang, jasa, dan/atau pelayanan administratif yang disediakan oleh penyelenggara pelayanan publik.

\section{Peningkatan Layanan Bidang Pendidikan Madrasah}

Pada dasarnya penyelenggraraan pelayanan publik adalah upaya untuk memuaskan masyarakat maka dari itu pelaksanaan pelayanan publik haruslah bersifat 1) Transparan, artinya terbuka dan mudah di akses oleh semua pihak, memadahi dan mudah dimengerti. 2) akuntabilas, artinya dapat dipertanggung jawabkan sesuai dengan SOP yang berlaku. 3) konsional, artinya Sesuai dengan kondisi dan kemampuan pemberi dan penerima pelayanan dengan tetap berpegang pada prinsip efisiensi dan efektivitas. 4) partisipatif, artinya mendorong semua pihak untuk berperan di dalamnya dengan memperhatikan aspirasi dan harapan masyarakat. 5) keseimbangan hak dan kewajiban, artinya penyelenggaraan pelayanan public tidak boleh diskriminatif kepada pihak tertentu serta menjalankan kewajiban masing masing.

Peningkatan kualitas pelayanan publik merupakan suatu upaya untuk meningkatkan kualitas dan inovasi pelayanan publik pada masing-masing instansi pemerintah secara berkala sesuai kebutuhan dan harapan masyarakat. Disamping itu, peningkatan kualitas pelayanan publik dilakukan untuk membangun kepercayaan masyarakat terhadap penyelenggara pelayanan publik dalam rangka peningkatan kesejahteraan masyarakat dengan menjadikan keluhan masyarakat sebagai sarana untuk melakukan perbaikan pelayanan publik.

Beberapa teknis yang harus dilakukan untuk meningkatkan pelayanan yaitu dengan membuat Standar Pelayanan Pengukuran indikator ini dilakukan dengan mengacu pada kondisi yang seharusnya dilakukan, seperti:

- Unit kerja telah memiliki kebijakan standar pelayanan;

- Unit kerja telah memaklumatkan standar pelayanan; 
- Unit kerja telah memiliki SOP bagi pelaksanaan standar pelayanan; dan

- Unit kerja telah melakukan review dan perbaikan atas standar pelayanan dan SOP.

Tak hanya membuat standard untuk meningkatkan pelayanan namun Budaya Pelayanan Prima juga perlu di berlakukan, budaya pelayanan prima adalah pelayanan yang ditujukan untuk memberikan pengetahuan dan ketrampilan mengenai bagaimana memperlakukan stakeholder/konsumen sehingga merasa puas dan dapat terjalin relasi jangka panjang. Lembaga pendidikan memiliki berbagi stakeholder yang memiliki keinginan dan harapan yang berbeda-beda. Ketrampilan hubungan personal dan memahami aspirasi konsumen (stakeholder). Adapun Pengukuran indikator budaya pelayanan prima dilakukan dengan mengacu pada kondisi yang seharusnya dilakukan, seperti:

Unit kerja telah melakukan sosialisasi/pelatihan berupa kode etik, estetika, capacity building dalam upaya penerapan budaya pelayanan prima.

- Unit kerja telah memiliki informasi tentang pelayanan mudah diakses melalui berbagai media.

- Unit kerja telah memiliki sistem reward and punishment bagi pelaksana layanan serta pemberian kompensasi kepada penerima layanan bila layanan tidak sesuai standar.

- Unit kerja telah memiliki sarana layanan terpadu/terintegrasi.

- Unit kerja telah melakukan inovasi pelayanan

Pelaksanaan pelayanan public di bidang Pendidikan Madrasah ( PENDMA ) Kementrian Agama Kabupaten Tuban menurut Bapak Hadi Sarjono selaku Plt. Pendidikan Madrasah, pelayanan public di lingkungan Pendidikan Madrasah setiap tahunnya terus ditingkatkan agar dapat memenuhi kebutuhan sesuai yang diharapkan oleh satuan kerja madrasah dan umumnya oleh masyarakat. Misalnya pelayanan untuk untuk pengajuan sertifikasi guru semua akan di layani secara cepat berbasis online menggunakan Simpatika jadi guru tidak perlu untuk datang cukup melengkapi data persayaratan yang ada di simpatika. Semua pelaksanaan yang di berikan telah sesuai dengan ketentuan 
perundang undangan yang telah ditetapkan oleh pemerintah dan juga juknis yang telah ditetapkan sebelumnya. Secara teknis alur penginformasian terkait adanya pelatiahan atau arahan apa pun baik dari wilayah mau pun dari pusat langsung di informasikan melalui grup whatsap untuk satuan kerja madrsah di wilayah kabutan tuban, tak hanya melaui grup whatsap Bidang Pendidikan Madrasah ( PENDMA ) juga bekerja sama dengan Bidang Humas untuk menyebarkan informasi terupdate melalui website Kementerian Agama Kabupaten Tuban.

Menurut bapak Khoirul Fata seksi Pendidik dan Tenaga Kependidikan menjelaskan setiap tahunnya banyak sekali pelatihan-pelatihan yang di progamkan dan telah dilaksanakan, baik pelatihan kurikulum, pelatihan peningkatan kompetensi guru, pelatihan kepala sekolah dan juga pelatihan untuk peningkatan mutu pendidikan madrasah yang lainnya. Hal itu di maksudkan agar senantiasa meningkatkan profesionalitas guru dan meningkatkan mutu pendidikan madrasah di Wilayah Kementrian Agama Kabupaten Tuban. Setiap tahunnya layanan pendidikan dan juga kesejahteraan pendidik dan tenaga kependidikan terus ditingkatkan sampai saat ini sudah ada 165 pengajuan dispensasi kelayakan tunjangan PTK yang sudah terverifikasi.

\section{Manfaat Pelayanan Public}

Menurut Wahyuni standar pelayanan publik berfungsi untuk memberikan arah bertindak bagi instansi penyedia pelayanan publik, di mana dengan ditetapkannya suatu standar atas pelayanan publik, maka dapat mempermudah instansi penyedia pelayanan untuk menentukan strategi dan prioritas. Terdapat dua manfaat standar pelayanan yang diungkapkan oleh Supranto dan Sugiyanti yaitu sebagai berikut: 1) Standar pelayanan memberikan jaminan mutu bagi pelanggan. Melalui standar pelayanan ini, masyarakat (pelanggan) dapat mengetahui apa saja yang diharapkan dari sebuah pelayanan. 2) Standar pelayanan dapat digunakan sebagai ukuran baku atas mutu yang harus ditampilkan oleh para petugas pelayanan.15

15 Sinta.unud.ac.id,kajian pustaka teori pelayanan publik, Diakses pada tanggal 20 oktober 
Menurut bapak Khoirul fata pelayanan public yang ada di bidang pendidikan madrasah menggunakan layanan berbasis teknologi informasi,dengan memanfaatkan apliksi seperti Simpatika untuk administrasi pendidik dan tenaga kependidikan dan juga emis untuk administrasi kelembagaan dan masih banyak lagi aplikasi - aplikasi yang bermanfaat untuk meningkatkan layanan public yang ada di wilayah Kementrian Agama Kabupaten Tuban. Pemanfaat teknologi informasi ini menjadikan layanan publik Bidang Pendidikan Madrasah ( Pendma) menjadi lebih cepat, efektif dan efisien. Untuk pengurusan surat pengajuan atau surat yang lain bisa di lakukan melalui melalui email atau di kirim lewat jasa pengiriman kecuali untuk layanan legalisir ijzah harus datang langsung ke Kemenag. Bidang Pendidikan Mandrasah senantiasa beruapaya memberikan pelayanan yang terbaik kepada masyarakat. Koordinasi dan pemberian informasi di berikan melalui grup whatsap kepala madrasah se kabupaten Tuban dan juga grup KKM kecamatan ada juga grup untuk pembinaan dan pembingan operator madrasah.

\section{Kendala Dalam Pelayanan Public}

Suatu birokrasi dikatan baik apabila terdapat kepuasan bagi masyarakat yang menikmatinya namun tak dapat dipungkiri bahwa dalam penyelenggaraan pelayanan terdapat hambatan hambatan yang menjadikan proses layanan public menjadi terkendala bahkan bias dikatakan pelayanan yang di berikan kurang memuaskan. Hal ini terdapat beberapa factor yang menjadi hambatan antara lain :

- Keterbatasaan sarana dan prasarana

Sarana dan prasarana merupakan hal pokok yang harus di penuhi dalam peningkatan layanan public. Ketersediaan tempat dan alat penunjang yang memadahi menjadi factor untuk memenuhi layanan public yang cepat dan efisien.

- Keterbatasan kemampuan dan sumberdaya manusia/aparatur

Lemahnya kemampuan dan sedikitnya sumberdaya manusia menjadi hambatan yang paling signifikat dirasakan, hal ini menjadikan tidak optimalnya pelayanan yang diberikan kepada masyarakat. 
- Kurangnya partisipasi masyarakat

Kerjasama antara masyarakat dan penyelenggara layanan public juga berpengaruh dalam proses pelayanan public. Ketika masyarakat tidak dapat bekerjasama dengan memenuhi kebutuhan terkait administrasi yang diperlukan untuk pemprosesan layanan maka layanan public pun tidak dapat terpenuhi secara optimal.

- Keterjangkauan akses.

Menurut bapak khoirul fata seksi Bidang Pendidikan Madrasah terdapat banyak sekali hambatan yang di hadapi dalam upaya pemberian layan public yang baik dan bermutu diataranya :

- Kurangnya partisipasi dari satuan kerja madrasah misalnya dari Bidang Pendidikan Madrasah sudah menetapkan batas akhir pengumpulan berkas pengajuan untuk dispensasi guru namun dari satuan kerja madrsah tidak mengirim sesuai dengan batas akhir yang telah di tetapkan. Kemudian tidak dipenuhinya kelengkapan administrasi padahal informasi telah di berikan dengan jelas.

- Keterbatasan sarana dan prasarana seperti akses internet untuk madrasah yang letaknya berada di daerah Kecamatan Senori yang berbatasan dengan Bojonegoro, kecamatan Montong yang berada di atas gunung dan daerah daerah yang jauh dari pusat keramaian lainnya. keterbatasan laptop / computer dengan spek yang mumpuni untuk digunakan menginput data baik PTK, Kelembagaan maupun siswa dan alat penunjang lainnya di tingkat satuan kerja madrasah.

- Sumberdaya manusia yang kurang mumpuni di tingkat satuan kerja madrasah, untuk mengatasi hal itu Bidang Pendidikan Madrasah (Pendma) senantiasa melakukan pendampingan dam pembimbingan melaui grup whatsap serta setiap tahunnya memberikan pelatihan untuk operator sekolah.

\section{Kesimpulan}

Pelayanan public ialah upaya pemberian layanan atau melayani keperluan orang atau masyarakat dan/atau pihak lain yang mempunyai kepentingan, sesuai dengan aturan pokok dan tata cara 
yang ditentukan dan ditujukan untuk memberikan kepuasan kepada penerima layanan.

Pelayanan public berkaitan erat dengan Hubungan Masyarakat (Humas) untuk menjalin hubungan komunikasi antara masyarakat dengan lembaga serta sebagai sumber informasi bagi masyarakat dan pihak yang berkepentingan lainnya.

Peningkatan pelayanan public dapat dilakukan dengan cara :

membuat standar layanan, menetapkan SOP kerja, melakukan review dan evaluasi, memberikan pelatihan terkait peningkatan layanan public

manfaat dari layanan public ialah adanya kepuasan dari stekholder/ pihak yang berkepentingan lainnya, meningkatnya keprcayaan masyarakat terhadap kinerja lembaga serta memudahkan stekholder/ pihak yang berkepentingan lainnya dalam memenuhi kebutuhan terkait dengan administrasi dll.

Kendala dari pelayanan public umumnya terjadi akibat kurangnya kapasitas, partisipasi, sarana dan prasana penunjang dari satuan kerja, operator atau pun stekholder / pihak lainnya.

\section{References}

Amirin Tatang M. 2011. “Manajemen Pendidikan”. (Yogyakarta: UNY Pres). 93.

Atik Septi Winarsih, Ratminto. 2016. "Manajemen Pelayanan: Pengembangan Modal Konseptual, Penerapan Culture Charter dan Standar Pelayanan Minimal". (Yogyakarta: Pustaka Pelajar). 1.

Broom, Cultip, Center. 2006. “Effective Public Releation(Edisi kesembilan)". (Jakarta: Kencana). 6.

Effendy Onong Uchjana. 2006. “Hubungan Masyarakat”. (Bandung: Remaja Rosdakarya). 23.

Elfidawati. 2016. "Manajemen Humas Dalam Meningkatkan Mutu Madrasah Studi Kasus di Madrasah Ibtidaiyah Terpadu (MIT) AS-SALAM AMBON". al- iltizam, Vol.1 No.1. Juni. 34. 
https://core.ac.uk/download/pdf/229359603.pdf. diakses pada tanggal 14 Oktober 2020.14.00

Jekins, Frank. 1992. "Public Realiton, Penerjemah Haris Munandar", (Jakarta: Erlangga). 92.

Jimmy Arief Saud Parsaoran. 2017. "Dasar - Dasar Pelayanan Publik Dalam Rangka Memenuhi Pelayanan Prima Di Sektor Pemerintahan".

http://bkpsdmd.babelprov.go.id/content/dasar-\%E2\%80\%93dasar-pelayanan-publik-dalam-rangka-memenuhi-pelayananprima-di-sektor-pemerintahan. diakses tanggal 21 oktober 2020.

Kurniawan Robi Cahyadi.2016. “Inovasi Kualitas Pelayanan Publik Pemerintahan Daerah". Fiat Justisia Journal of Law. Vol.10 No.03. 573.

Moenir. 1995. "Manajemen Pelayanan Umum". (Jakarta: PT Bumi Aksara). 7.

Rahmawati. 2014.“Administrasi dan Pelayanan Publik Ditinjau Dari Kemaslahatan Umat". jurnal pilar Vol.02 No.02 juli-desember 2014.199-200.

Sadhana , Dr. Kridawati, M.S. 2010. “Etika Birokrasi dalam Pelayanan Publik". (Malang: CV. Citrab Malang) 131.

Satriadi. dkk . 2018. "Kualitas Pelayanan Publik Sektor Pendidikan

(Studi Pelayanan Program Dana Bos Tingkat Sma Pada Dinas Pendidikan Kota Tanjungpinang)". jurnal manajemen dan bisnis tanjung pinang, Vol.02 No.01. 30-31.

Siagian, Sondang P. 1982. "Filsafat Administrasi". (Jakarta: Gunung Agung). 96.

Undang-Undang Republik Indonesia Nomor 20 Tahun 2003. 